Brazilian Journal of Political Economy, vol. 32, nº 4 (129), pp. 634-655, October-December/2012

\title{
Exchange rate pass-through inflation and wage differentials in late-industrializing economies: the Mexican case
}

\author{
TERESA S. LÓPEZ \\ GUADALUPE MÁNTEY \\ LUIS QUINTANA*
}

This paper investigates exchange rate pass-through inflation, and the wage bargaining process, in a developing economy in which firms' market power is largely dependent on technical progress embodied in imported intermediates and capital goods. It develops a heterodox model of income distribution, based on theoretical contributions from Latin American structuralists, labor market segmentationists and post-Keynesian writers, and it presents supportive empirical evidence from the Mexican economy.

Keywords: income distribution; inflation; developing economies.

JEL Classification: E11; E12; E31; J31; O11.

\section{INTRODUCTION}

Conventional macroeconomic theory, by assuming representative agents and competitive markets, has been unable to deal with the heterogeneous structures of production typical of developing countries.

Many writers have denied the uniqueness of economic theory, particularly

\footnotetext{
* Universidad Nacional Autónoma de México, Facultad de Estudios Superiores Acatlán. E-mails: terelogo@prodigy.net.mx,gmantey@unam.mx, luquinta@apolo.acatlan.unam.mx. This research benefited from the financial support of the National Autonomous University of Mexico, through PAPIIT Project IN300610. We gratefully acknowledge the observations and suggestions received from two anonymous referees, that largely improved the original manuscript. Any remaining errors are our responsibility. Submitted: 25/April/2011; Approved: 8/November/2011.
} 
with regard to growth constraints and inflation determinants, in semi-industrialized countries.

In the late 1940s, a group of economists working at the United Nations Commission for Latin America claimed that the development process in backward economies could not be explained as a stage of capitalist development following the same path of early industrialized nations (Prebisch, 1949, 1983; Rodríguez, 1980; Bielchowsky, 1998). Their analyses were based on the historical evolution of economic relations between rich and poor countries, and the specialization in foreign trade that ensued. The center-periphery models they elaborated emphasized differences in production patterns resulting from less developed countries' technological backwardness, which made them exporters of raw materials and importers of capital goods and intermediates.

One point stressed by these writers - which has been notably neglected in mainstream macroeconomics - is that currency devaluations become strongly inflationary when there is a sizeable technological dependence from abroad, and when the Marshall-Lerner condition is not fulfilled. The basic forces that produce structural inflation, as this phenomenon was named, cannot be imputed to monetary expansion; but rather, the increase in money supply that accompanies currency depreciation is one mechanism by means of which developing countries solve the distribution conflict brought about by the exchange rate adjustment (Lustig, 1988; Camara and Vernengo, 2001).

In the early 1960s Chenery argued that growth models were inadequate as a basis for development policy, because they neglected important questions that constrain growth in developing economies, such as foreign exchange availability and technological dependence on developed countries (Chenery and Bruno, 1962).

Thirlwall $(1979,2003)$ has further developed these ideas, in his influential balance of payments constrained growth model, where the income elasticities of exports and imports determine the long-run path of a country.

In this paper, we investigate the exchange rate pass-through inflation, and the wage bargaining process, in a developing economy where firms' market power is largely dependent on technical progress embodied in imported intermediates and capital goods. Our main objective is to establish how conflicting claims on income are eventually settled in this type of economy, in order to assess the inflationary consequences of currency devaluation, monetary policy and labor market behavior.

The paper is divided into six sections. In the first section, we review the determinants of exchange rate pass-through inflation and factor income distribution under different market structures. On the basis of this information, we conjecture the likely effects of currency depreciation in an economy in which oligopolistic firms are the price leaders.

In the second section, we formalize a model of pricing and income distribution under imperfect competition.

Then, we introduce two peculiarities of a developing economy into the analysis. We consider an excess supply of unskilled labor, and a strong dependence on imported capital goods and technology, and we postulate that firms' market pow- 
er is based on their technical advances. Then, we examine the consequences of such assumptions through the model presented, illustrating them with statistical data on the Mexican economy.

In the next section, we use our analytical framework to study the effects of increased international capital mobility and speculative investment on factor income distribution in developing countries.

In the fifth section we present an empirical estimation of the model with quarterly data on the Mexican economy from the 1978-2010 period. We conclude with a few policy recommendations derived from our econometric results.

\section{EXCHANGE RATE PASS-THROUGH INFLATION AND INCOME DISTRIBUTION UNDER DIFFERENT MARKET STRUCTURES}

The new consensus in macroeconomics rests on the neoclassical theory of income distribution, dependent on the marginal productivities of productive factors, and a hybrid theory of inflation that reconciles rational expectations on future inflation with the Keynesian Phillips curve (Panico and Salvadori, 2006). In this framework, inflation $(\mathrm{P})$ depends on nominal wage increases and the output gap (or the change in unit labor costs, ULC), as well as on past and rationally expected inflation (Romer, 2000; Svensson, 1997; Galí et al., 2001). In open economy models, the direct effect of exchange rate changes (E) on import prices is also incorporated (Svensson, 2000; Ball, 2000).

$$
\Delta \mathrm{P}=\mathrm{ULC}+\beta \mathrm{E}
$$

where $\beta$ represents the share of imports in gross domestic product.

In line with neoclassical theory, this approach disregards imperfect competition and distribution conflict, along with the corresponding equilibrium correction mechanisms.

The pioneering work of Kalecki (1956) has ever since inspired a long stream of mark-up pricing models that aimed to explain the behavior of firms under imperfect competition. In the late 1980s, multinational firms' pricing behavior under imperfect competition received specific attention, because of the unexpected effects from exchange rates variation on import and export prices, as well as on the trade balance of major industrial countries (Krugman and Baldwin, 1987).

Empirical evidence indicated that pricing to market was a common practice for multinational enterprises in international trade, and exchange rate pass-through imports prices was incomplete. Arestis and Milberg (1993) studied this phenomenon within the framework of Eichner's model. Notwithstanding they were primarily concerned with foreign firms' pricing behavior in developed countries, we believe their analytical framework may also be useful to explain the inflationary consequences of currency devaluations in less developed countries.

Eichner developed a theory to explain the behavior of the price leader in an oligopolistic market structure. 
He postulated that the mark-up would be dependent upon the firm's demand for investing resources and supply conditions of additional finance. The leading firm would be planning its investment outlays on the basis of the new assets' marginal productivities; and in so doing, it would decide how much of the required finance should come from retained earnings, and how much it should raise from financial markets.

Because of its market power, the firm would be able to increase the mark-up in order to finance its desired expansion. Nevertheless, this option can be expected to involve costs in the future, to the extent that the firm's customers find substitutes for the product; new competitors enter the market, or the government decides to raise the tax levy.

Eichner assumed these trade-offs could be estimated by the leader, who would eventually resort to internal finance, up to the point where its expected cost equaled the market rate of interest.

One important implication of this theory, which we shall return to later, is that an expansionary monetary policy that lowers the rate of interest would actually be deflationary, and not inflationary as mainstream economic theory postulates. Credit availability, at moderate interest rates, would discourage firms with market power from raising funds internally, thereby contributing to stabilizing prices.

Following Eichner, Arestis and Milberg (1993) define the price charged by an individual firm $(\mathrm{P})$ as the sum of average variable cost (AVC), plus fixed costs (FC) and the corporate levy (or the cost of internal finance, CL) per unit of output, assuming the firm operates at normal capacity. Normal capacity is defined as the product of the standard operating ratio (SOR) times the engineering rated capacity (ERC):

$$
\mathrm{P}=\mathrm{AVC}+[(\mathrm{FC}+\mathrm{CL}) /(\mathrm{SOR} * \mathrm{ERC})]
$$

For a foreign firm operating in the domestic market, the right-hand side of the above equation would have to be multiplied by the exchange rate (e).

Variations in the exchange rate would translate into price changes in proportion to their effects on: i) average variable costs; ii) the firm's projects for expansion, as well as the required financing to carry them out; and iii) domestic interest rates.

Eventually, the pricing decision for the foreign firm, as well as for national corporations, will depend on average variable costs expressed in the local currency, the level of desired investment, the implicit cost of internal funds (i.e., by raising the product price), and the interest rate on borrowed funds.

Depreciation of the local currency brings about a rise in the implicit cost of internal funds for the foreign firm, since its average variable cost and overheads expressed in the local currency increase, and its competitive position vis-à-vis rival domestic corporations deteriorates. A rise in the internal cost of funds, in this model, would lead to a fall in the mark-up; that is, to an incomplete exchange rate pass-through. The foreign firm would be compelled to finance its new investments by means of additional borrowing.

If aggregate demand in the local market shrank in response to the currency 
depreciation, the cost of internal funds for all corporations would rise further, mark-ups would fall to a larger extent, and the exchange rate pass-through would still be more limited.

On the grounds of Eichner's model, and assuming the corporate levy represents the objective variable for the firm, the rate of inflation would depend on the expected profitability of new assets, the market rate of interest, and unions' bargaining power. If the marginal productivity of investment rose (i.e., because embodied technical progress involved increased efficiency, product differentiation etc.), and everything else remained the same, the mark-up would widen and real wages would fall. Since workers' expectations would be disappointed, at the following wage negotiation, labor unions would exert pressure on firms' management in order to get a share in productivity gains.

Post-Keynesian mark-up pricing models assume wage bargaining is carried out in nominal terms, even though workers strive for a target real wage (Arestis and Skuse, 1991; Sawyer, 1982). Among the variables that influence labor demands, these models consider market conditions, price expectations, the highest real wage hitherto observed, and prevailing wage differentials among different groups of workers. Eventually, however, it is mark-up pricing that determines income distribution.

The important question here, in order to disclose the effect of nominal wage rates on inflation, is to what extent unions become satisfied when they hit the real wage rate target and/or maintain wage differentials with other groups of workers. If these are their main objectives, as several authors affirm, then it is irrelevant that wage bargaining is conducted in money terms; for the real wage rate would eventually be historically determined (Sawyer, 1982).

Joan Robinson argued that trade unions are not always conscious of the extent to which wages should rise, provided they rise at all. She pointed out that accordingly, when technical progress enables innovators to pay wages above market rates, by lowering average costs, the latter become allies of trade unions, even though eventually the degree of monopoly rises (Robinson, 1966, p. 94).

In these theoretical approaches to income distribution under imperfect competition, one finds two pervasive ideas. First, that in oligopolistic product markets, capital accumulation is a defensive policy by means of which the price leading firm strengthens its market power. Second, that the productivity gains from embodied technical progress are initially appropriated by oligopolistic entrepreneurs, who share them with their employees only later, and always in a discretional manner (i.e., since eventually real wages depend on mark-ups), either under the pressure of labor unions, or by their own initiative.

As a matter of fact, these two ideas are at the core of segmented labor market theory.

Segmentationists claim that oligopolistic firms establish institutional constraints on wage behavior, and create job structures internal to the firm, in order to protect their profits from the ebb of market forces (Leontaridi, 1998). Labor market segmentation also responds to entrepreneurs' interest in minimizing absenteeism and turnover in those activities where on-the-job training is important. As 
a result of this behavior, workers in oligopolistic firms are not paid according to their productivity or skills, but on the basis of institutional seniority privileges and custom (Gordon, 1972).

The proponents of this approach distinguish two types of labor markets: first, the primary market, which includes the best jobs, and is characterized by high wages; on-the-job training; economic security and career advancement; employment relations governed by formal rules previously agreed upon with labor unions; and isolation from outsiders' competition.

By contrast, the secondary market clusters the worst jobs, or those not requiring special skills. In this market, wages are determined by supply and demand; individual incomes depend more heavily on variations in working hours than on wages; working conditions are unfavorable; employment is variable; and there are few opportunities for advancement (Piore, 1971).

Since training costs differ among industries and firms, the primary market is balkanized (Leontaridi, 1998); each oligopolistic firm builds up its internal job ladder and wage structure, which are connected with the external market through only a few "ports of entry". At these points, workers recruited by the oligopolistic firm are paid a wage above the market rate, but as they are trained and upgraded, their wages rise according to the institutional rules set by the firm. In this way, a part of the gains in total factor productivity, brought about by technical progress, are redistributed in a discretional way among skilled workers (Blanchflower et al., 1996).

It thus follows that nominal wage increases in the primary market cannot be a source of inflationary pressures, since they are administered by the firm on the basis of its target profit margin and its desired rate of accumulation.

Nominal wage increases in the secondary market might have inflationary effects, to the extent that they exert pressure on wages at primary markets' ports of entry. Nevertheless, since at these points the oligopolistic firm actually bids up the external market rate, and there is scope to compensate for a higher starting wage by shrinking wage differentials at the upper levels of the internal wage structure, its impact on the average variable cost would be limited.

Hence, we may conclude that under conditions of oligopolistic competition and segmented labor markets, it is unlikely that skilled labor nominal wage increases become a source of inflationary pressures; rather, one may expect that primary labor markets behave as buffers that mitigate the distributive conflict that causes inflation.

\section{STYLIZED FACTS IN EXCHANGE RATE PASS-THROUGH AND INCOME DISTRIBUTION UNDER AN OLIGOPOLY}

The hypothesized behavioral pattern of an economy under oligopolistic competition may be represented by the following system of equations that define the price level (P), the unit labor cost (ULC) and the skilled-unskilled labor wage differential (DIF). 
The price level $(\mathrm{P})$ is dependent on the exchange rate (ER), the unit labor cost (ULC), and a random error $\left(\mathrm{u}_{1}\right)$ :

$$
\mathrm{P}=\alpha_{1}+\alpha_{2} \mathrm{ER}+\alpha_{3} \mathrm{ULC}+\mathrm{u}_{1}
$$

where $\alpha_{2}>0$ and $\alpha_{3}<0$

The main difference with the conventional price equation in Section 1 is the negative sign of $\alpha 3$, the unit labor cost coefficient, which is explained by the rentsharing mechanism assumed in primary labor markets.

Unit labor cost (ULC) is a function of technical conditions of production, which we assume constant in the short run, but falling in the long run as a result of technical progress; wage rates in both primary $\left(\mathrm{W}_{1}\right)$ and secondary $\left(\mathrm{W}_{2}\right)$ labor markets; and a stochastic disturbance term $\left(\mathrm{u}_{2}\right)$. The primary market wage rate is expressed as a wage differential (DIF) with respect to the wage rate in the secondary market; and the latter is assumed to be dependent on the institutionally determined minimum wage (Wmin), so that:

$$
\begin{aligned}
& \mathrm{DIF}=\mathrm{W}_{1} / \mathrm{W}_{2} \\
& \mathrm{ULC}=\beta_{1}+\beta_{2} \mathrm{DIF}+\beta_{3} \mathrm{~W}_{\min }+\mathrm{u}_{2} \\
& \text { where } \beta_{2}, \beta_{3}>0
\end{aligned}
$$

The wage differential equation portrays a rent-sharing process. The constant term reflects the structural elements, such as income distribution in society and the degree of product market oligopoly, determining efficiency wages at the ports of entry into firms' internal job structures. The two explanatory variables indicate the profit stabilizing role of skilled labor pay-roll.

It is assumed that skilled labor wage differentials shrink when the overall level of employment (EMP) rises, and wages in the secondary (competitive) market start to climb.

On the contrary, skilled workers' wage differentials swell if firms have easy access to credit that lowers their financial costs.

$$
\begin{aligned}
& \text { DIF }=\gamma_{1}+\gamma_{2} \text { EMP }+\gamma_{3} \text { CRED }+u_{3} \\
& \text { where } \gamma_{1}, \gamma_{3}>0 \text { and } \gamma_{2}<0
\end{aligned}
$$

The model assumes an oligopolistic market structure, in which currency devaluation brings about a fall in economic activity (Krugman and Taylor, 1979).

If central banks tighten monetary policy after the exchange rate adjustment, as they usually do, with the aim of moderating its inflationary consequences, credit stringency further slows down income growth.

An increase in unemployment depresses wages in the secondary labor market, and also strengthens oligopsony in primary labor markets, in which labor productivity can be enhanced by means of the criteria applied in internal job evaluations. As the productivity of the previously employed skilled workers increases, some of them will be dismissed, and new job opportunities for unemployed skilled workers will also be spared. 
Skilled workers' wage differentials will increase as unskilled workers' wages decline, but credit stringency operates in the opposite direction.

Rising unemployment on the whole, and declining wages in the secondary market, are likely to reduce labor costs. Therefore, it is not surprising that an increase in inflation, brought about by currency devaluation, coincides in time with a fall in unit labor costs. In fact, under conditions of oligopolistic competition, as the workers' share in income declines, and the income multiplier falls, the contractionary and inflationary effects of devaluation become stronger, because in such circumstances, price leading firms prefer to adjust the quantity supplied rather than their price.

Recursive substitution of Equations (2.2) and (2.3) into Equation (2.1) leads to the following reduced form of the inflation function:

$$
\mathrm{P}=\delta_{1}+\delta_{2} \mathrm{ER}+\delta_{3} \mathrm{CRED}+\delta_{4} \mathrm{EMP}+\delta_{5} \mathrm{~W}_{\min }+\mathrm{u}_{4}
$$

where $\delta_{2}, \delta_{4}>0$; and $\delta_{3}, \delta_{5}<0$

It can be seen, from the signs of $\delta_{2}$ and $\delta_{3}$, that the inflationary impact of currency devaluation is amplified when it is accompanied by a tight monetary policy, and together bring about a fall in capacity utilization.

Contrariwise, the opposite signs of $\delta_{4}$ and $\delta_{5}$ indicate that the inflationary effect of rising employment, during a cyclical expansion, tends to be offset by the deflationary effect of higher capacity utilization due to workers' increasing demand.

\section{EXCHANGE RATE PASS-THROUGH AND INCOME DISTRIBUTION IN A DEVELOPING ECONOMY}

In this section, we introduce into our analytical framework two peculiarities of the developing economy: i) an excess supply of unskilled labor; and ii) a high degree of dependence on imported capital goods and technology.

We assume that oligopolistic firms' market power is based upon imported technology and capital goods; and investigate the inflationary effects of bank credit expansion, exchange rate depreciation, and skilled labor wage bargaining.

\section{Credit expansion and inflation}

In such a model, bank credit expansion would, by lowering the loan rate, diminish the maximum cost the oligopolistic firm would be willing to incur, in the case of raising the funds required for investment from its earnings (corporate levy). Since mark-up depends positively on the corporate levy, prices would tend to fall.

In this framework, bank credit cannot be inflationary for two reasons: first, because under oligopolistic competition there is always excess capacity; and second, because the bank credit likewise granted to oligopolistic firms would enable them to undertake new projects and benefit from technical progress.

Notwithstanding that in our model, credit expansion has a negative effect on 
prices (because of its inverse relation to interest rates), it is important to notice that it may actually become inflationary in an indirect way, if it brings about an excess of imports over exports, prompting currency depreciation. We deal with this problem in the following section.

In a developing economy, where technical progress is embodied in imported material inputs and factor services, and the Marshall-Lerner condition does not hold, foreign producers naturally become the price leaders.

On the basis of Eichner's model, one should expect that an exchange rate depreciation, under such circumstances, would bring about an amplified effect on domestic inflation, and not the incomplete pass-through observed in industrialized countries, because:

- it would raise the cost of investment projects expressed in the local currency, and therefore the corporate levy;

- the prices of the imported inputs that form part of the variable cost would also increase;

- expectations of recession would induce local producers to raise their mark-ups, without fear of foreign competition;

- the monetary authority would be moved to raise the rate of interest, in order to soothe inflation, thereby increasing firms' financial costs (Palley, 2002).

It is for these reasons that, in a developing economy, currency devaluation does not contribute to stabilizing the balance of payments, but rather it sets out a devaluation-inflation-devaluation spiral.

Latin American structuralists arrived at the same conclusion, though they explained it on different grounds, as the result of an inelastic supply of tradable primary goods and commodities in the short run, and an inelastic demand for imports during the early stages of industrialization (Prebisch, 1983; Rodríguez, 1980; Noyola 1957; Pinto, 1975).

More recently, other authors have explained the large exchange rate passthrough inflation in developing countries as a result of their incapacity to borrow abroad in their own currency ("original sin") and their liabilities dollarization (Eichengreen, 2002; Calvo and Reinhart, 2000; Eichengreen et al., 2003).

\section{Wages and inflation}

In this section, we use the analytical framework developed to trace the effects of skilled labor wage increases on the inflation rate in a developing economy.

We refer to skilled labor wages in particular, and not to the average wage rate, for two reasons: first, because it is usually assumed that in developing economies the shortage of educated manpower causes inflationary pressures, as economic activity grows and entrepreneurs bid up for white collar employees; and secondly, because we intend to disclose the influence that the excess supply of unskilled labor exerts on the secondary market wage rate, and from there, on the distribution of income in the oligopolistic firm. 
On the basis of segmented labor market theory, one would expect that an excess supply of unskilled labor would keep real wage rates in the secondary market at a very low level. Even though this theory rejects the possibility of arbitrage between the two markets, it is conceivable that what people consider to be a "fair wage" for a skilled worker is related in some way to the average wage for unskilled workers. From here it would follow that the wage rate at the lowest port of entry to the internal wage structures of oligopolistic firms would also be low.

If workers and unions behaved as it is usually assumed they do, and if:

1. they were mainly concerned with achieving a target real wage rate, which is proxied by the largest one they got in the past; and

2. they aimed at maintaining their wage differentials with respect to other groups of workers;

oligopolistic firms would have wide scope to let skilled workers share in the productivity gains from technical progress, without impairing their growth prospects.

Given that in a surplus (unskilled) labor economy the recruiting wage rates at the bottom of the oligopolistic firms' internal job structures would be permanently pulled down by the (low) average wage in the secondary market, the latter would operate as a nominal anchor for every wage structure in the primary markets. In countries where market forces, if left unrestricted, would drive the unskilled labor wage rate below a tolerable level, and where a minimum wage is enforced by law, this institutionally determined wage rate fulfils the anchor function for the two segments of the labor market.

In this analytical framework, it is conceivable that the decision on the productivity gains from technical progress that the oligopolistic firm distributes among its employees will be dependent on the corporate levy; that is, on that part of the firm's financial needs that must be satisfied with internal funds. Since the corporate levy is positively associated with the loan rate of interest, one should expect that skilled workers' wage differentials with respect to unskilled workers will be inversely dependent on interest rates, and directly related to credit availability.

The main conclusion that we derive from this analysis is that the process of skilled labor wage determination, by its nature, is not a source of inflationary pressures. Causality would go in the opposite direction: from price rises brought about by an increasing degree of monopoly, to skilled labor administered wages. If productivity had not grown, skilled labor wages would not have been raised.

Hence, productivity gains and the labor sharing factor are direct functions of investment growth and credit availability. From this point of view, credit expansion and economic growth could actually be deflationary, and could reduce income inequalities, provided imports do not exceed export capacity.

This brings our analytical framework close to Thirlwall's growth model (Thirlwall, 1979) on two important issues: first on the sustainability of economic growth, which according to Thirlwall's Law would be dependent upon the income elasticities of exports and imports, and secondly, on the positive effect of aggregate demand on labor productivity, which would account for a negative relationship between investment and inflation (i.e., Verdoorn's Law). 
Nevertheless, our model differs from this approach on three points: i) its explicit consideration of firms' market power based on imported technology and capital goods; ii) the assumption of an excess supply of unskilled labor and segmented labor markets; and iii) the adoption of Eichner's theory of the determinants of firms' mark-up under oligopoly.

These elements bring about distinct conclusions on the role of wages and exchange rates on inflation and income distribution in developing economies.

\section{CAPITAL MOBILITY, SPECULATIVE INVESTMENT AND THE DESIRED RATE OF ACCUMULATION}

In Eichner's model, the firm's planned investment is exogenously determined, and therefore it is neither affected by the market rate of interest nor by the cost of internal funds. Obviously this is an unrealistic assumption.

In any open economy, speculative investment in foreign assets, and capital gains on financial assets (brought about by changes in domestic and international interest rates, as well as in the exchange rate) determine changes in productive investment decisions.

Taking into account that worldwide financial deregulation and innovation have increased capital mobility, we may assume that through arbitrage they have led to the establishment of a minimum profit margin on international financial investments that sets a floor to productive investment profitability.

In a developing economy, where currency depreciations are usually large, and followed by analogous increases in inflation and interest rates, along with a decline in economic activity, asset substitution is more intense.

In the last section, we concluded that skilled labor wage rates were administered prices in the oligopolistic firm, and behaved like buffers in resolving the conflicting claims on income. Seeing that labor immigration confronts political opposition in almost every country, while international capital inflows are usually welcome, it is conceivable that the different degree of mobility of capital and labor reinforces the passive role of wage rates in the inflationary process.

In fact, the threat posed by international capital mobility has led developing countries to undertake economic policies and institutional reforms that lower the risks and enhance the profitability of foreign investments, at the same time that they establish institutional reforms aimed at deregulating the labor market (FitzGerald, 2005; Alvarez, 2002).

From the model we have developed so far, it is evident that labor market flexibility plays a key role in the competitive strategy of oligopolistic firms in developing countries, mainly when anti-inflationary policy relies on exchange rate overvaluation.

In the following two sections, we present empirical evidence on price and wage behavior in the Mexican economy, which cannot be satisfactorily explained by other approaches to income distribution and inflation, but are consistent with the conclusions derived from the model outlined in this paper. 


\section{STRUCTURAL INFLATION AND UNIT LABOR COSTS IN A DEVELOPING ECONOMY}

Mexico is a typical example of a developing economy subject to structural inflation (see Graph 1). Various estimates of the exchange rate elasticity of inflation indicate it approaches unity ${ }^{1}$. Granger causality tests systematically indicate that exchange rate variations anticipate consumer price changes, and not the other way around, as relative purchasing parity theory holds (Martínez et al., 2001; Mántey, 2006).

The tests give unambiguous significant results with quarterly lags from 1 to 40 .

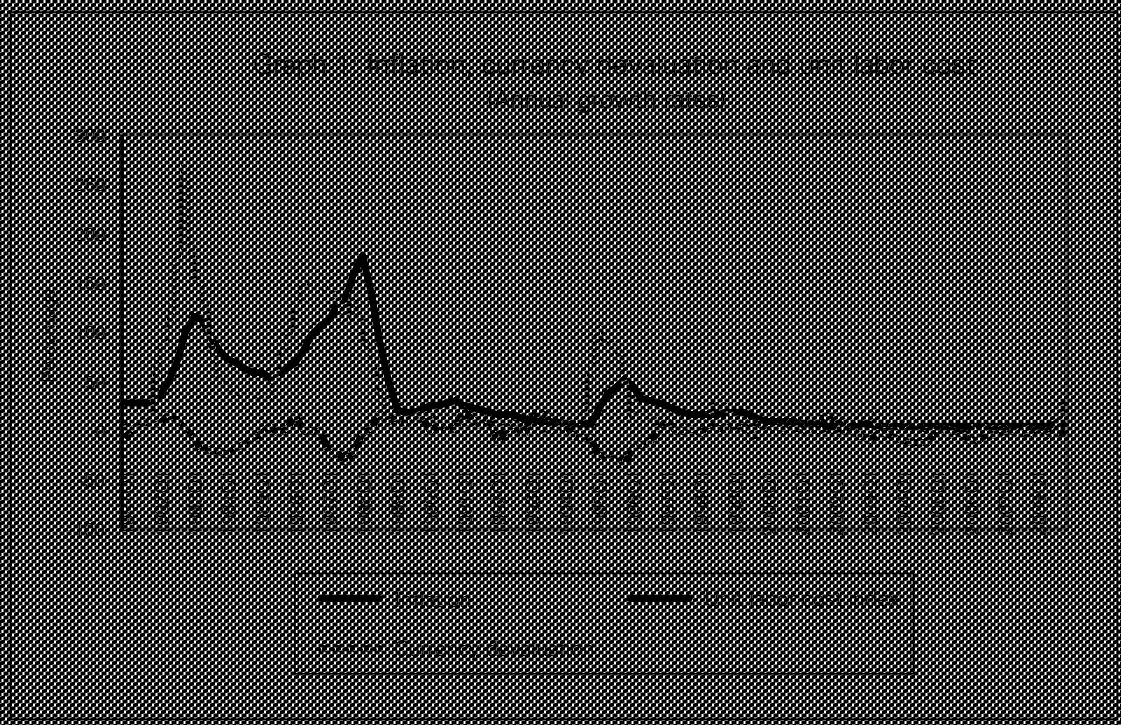

In addition, labor organization in Mexico has been traditionally weak. In the manufacturing industry, only $20 \%$ of firms report unionized labor (López and López, 2006); and a tripartite body, in which representatives of the government, entrepreneurs and labor unions participate, settles the minimum wage rates for blue and white collar activities, which operate as guidelines for industry and firm wage contracting. These elements, as we shall see, account for the unusual inverse relationship that Graph 1 reveals, between the rate of inflation and changes in unit labor costs in manufacturing.

These two phenomena contrast sharply with the experience of developed coun-

\footnotetext{
${ }^{1}$ Galindo et al. (2007), on the basis of a cointegration price equation and an error correction model estimated for the 1985-2006 period, derive an exchange rate pass-through of 0.66 in the long run, and of 0.32 in the short run. Using the same methodology, but for the 1980-2002 period, Mántey (2006) obtained 1.07 for the pass-through in the long run, and 0.15 in the short run. For large devaluations, Garcés (1999) computed a long run pass-through of unity. In the tradable goods sector, Martínez et al. (2001) reported the exchange rate pass-through inflation was 0.83 in the 1997-2000 period.
} 
tries. Arestis and Milberg (1994), in their investigation of the inflationary effects of exchange rates and unit labor costs in Great Britain and the United States during the 1972-1989 period, found that in the former country, the exchange rate passthrough coefficient was 0.009 , while the absolute values of the coefficients for wage and productivity increases were 0.474 and 0.341 , respectively. In the United States, the absolute values of the same coefficients were $0.015,0.375$ and 0.001 .

Calvo and Reinhart (2000), who also estimated the exchange rate passthrough inflation in a sample of 25 countries from 1970 to 1999 , observed that in emerging economies it was four times greater than in developed countries.

We argued earlier that the magnified response of inflation to exchange rate variations in a developing economy was a result of its dependence on imported technology, and of domestic firms' market power being based upon imported capital goods and intermediates. Since these issues have been largely studied, not only by the Latin American writers already mentioned, but by other authors as well (Palley, 2001; Taylor, 1983; Hernández-Barriga, 2009; Ampudia, 2007; Mántey, 2005), we shall concentrate here on explaining the inverse relationship between unit labor costs and inflation.

Unit labor costs vary directly with wage rate changes, and inversely to labor productivity growth. In Mexico, fixed investment, gross domestic product, and the marginal output/capital ratio are highly correlated (see Graph 2), thereby indicating not only the effectiveness of the investment multiplier, but also the generation of productivity gains from embodied technical progress.

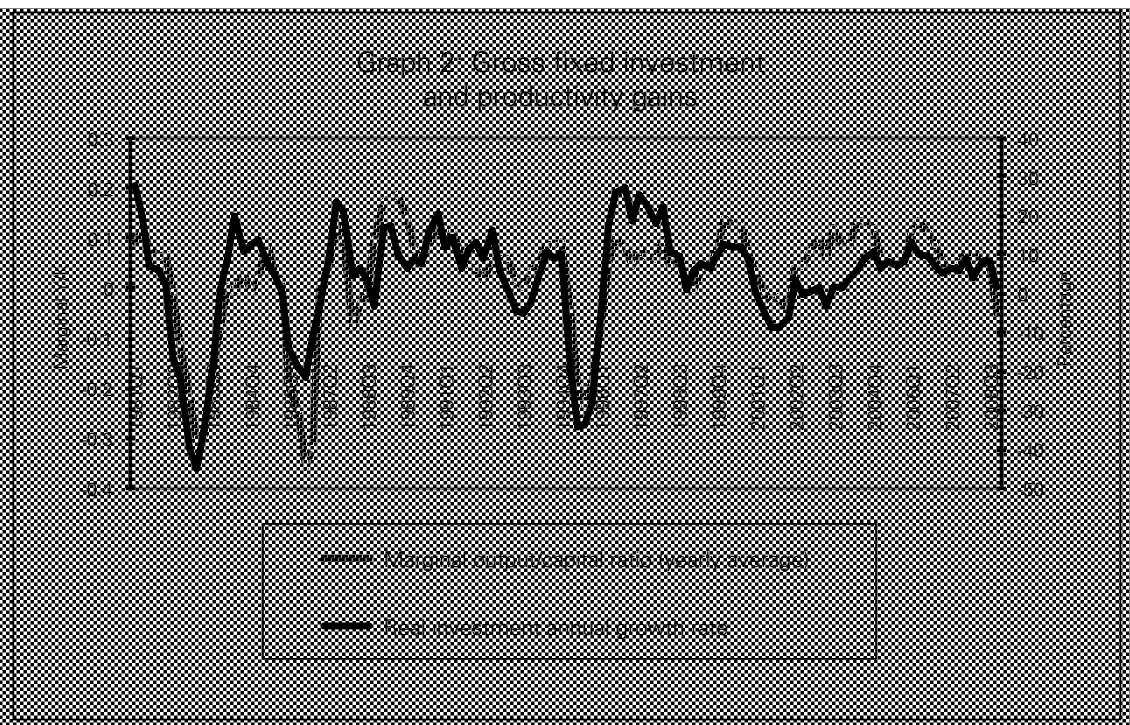

Source: Calculations based on data from banco de Mexico and INEGI. 
Fixed investment is inversely related to exchange rate behavior, as we anticipated, because of the high degree of substitution between productive assets and deposits in foreign currencies, in firms' investment decisions (see Graph 3).

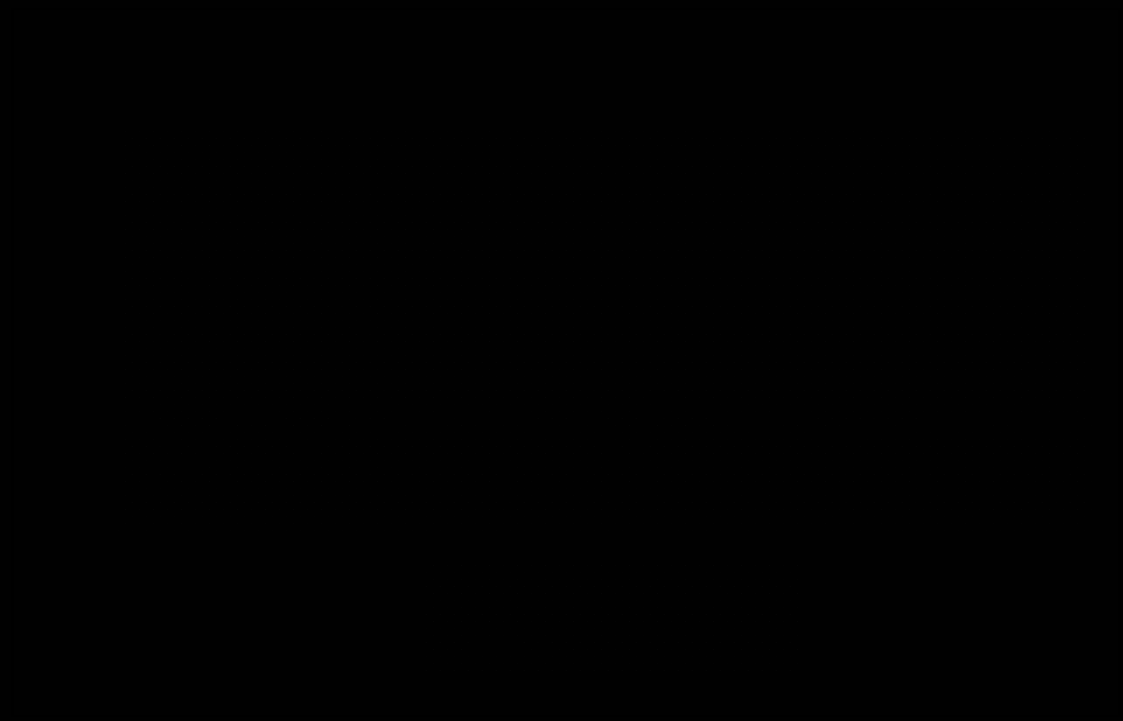

Source: Calculations based on data from banco de Mexico and INEGI.

It is for this reason that, when the national currency appreciates, and the rate of inflation falls, investment flourishes and total factor productivity increases. Under these circumstances, price leading firms are better disposed to share a part of the productivity gains with their skilled workers, so the average real wage increases; but since wages rise only after productivity gains have been realized, a change in investment is followed by a change in the same direction in unit labor cost. Conversely, when fixed investment falls, and productivity growth declines, skilled labor real wages are likely to stagnate, and unit labor costs go down.

For this reason, currency depreciation coincides in time with a rise in the inflation rate, and also with a fall in unit labor costs; while currency appreciation stabilizes domestic prices, and brings about a rise in unit labor costs.

Hence, in a developing labor surplus economy, heavily dependent on imported capital goods and technology, the labor market operates like a buffer that absorbs the shocks that otherwise would lead to an inflationary solution to resolve conflicting claims on income. Let us consider the case of trade openness with currency overvaluation.

From the early 1980s to the mid-1990s, the Mexican economy went through a swift process of deregulation and opening, in which the real exchange rate varied widely, often exposing domestic industry to foreign competition in unfavorable 
terms. Under these circumstances, manufacturing firms were compelled to increase labor productivity, which they achieved in the short run mostly by lowering employment (see Graph 4).

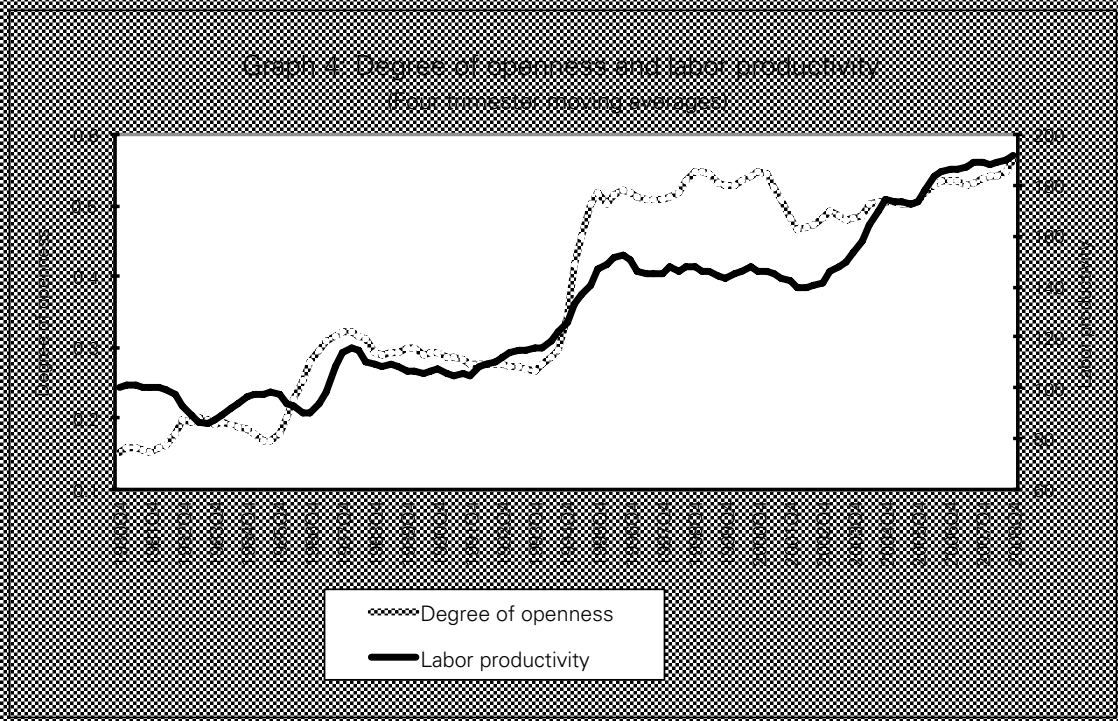

Notes: Openness was proxied by the ratio of exports plus imports to GDP.

Labor productivity was proxied by an index of output per worker at 1993 prices.

Source: Calculations based on data from Banco de Mexico and INEGI.

While output per worker in manufacturing increased by more than $92 \%$ in real terms from 1980 to 2008, the institutionally determined minimum wage lost two thirds of its purchasing power in the same period. The average unskilled labor real wage in that sector decreased $22 \%$; and the skilled labor real wage showed the largest swings, ending only $8 \%$ above its 1980 level (see Graph 5).

In Graph 5 we can observe that the three wage rate series underwent similar behavior with respect to their turning points; whereas labor productivity behaved differently, with its turning points not always coinciding with the former.

These facts are consistent with two of our assumptions: first, that in the wage bargaining process, labor unions' prime concern is to defend wage differentials; and second, that firms share productivity gains with white collar workers on a discretional basis.

Skilled labor wage rates exhibit the same pattern of twists as unskilled labor wages, but they were not pulled downwards by the institutional minimum wage. Accordingly, skilled workers' wage differentials widened. 


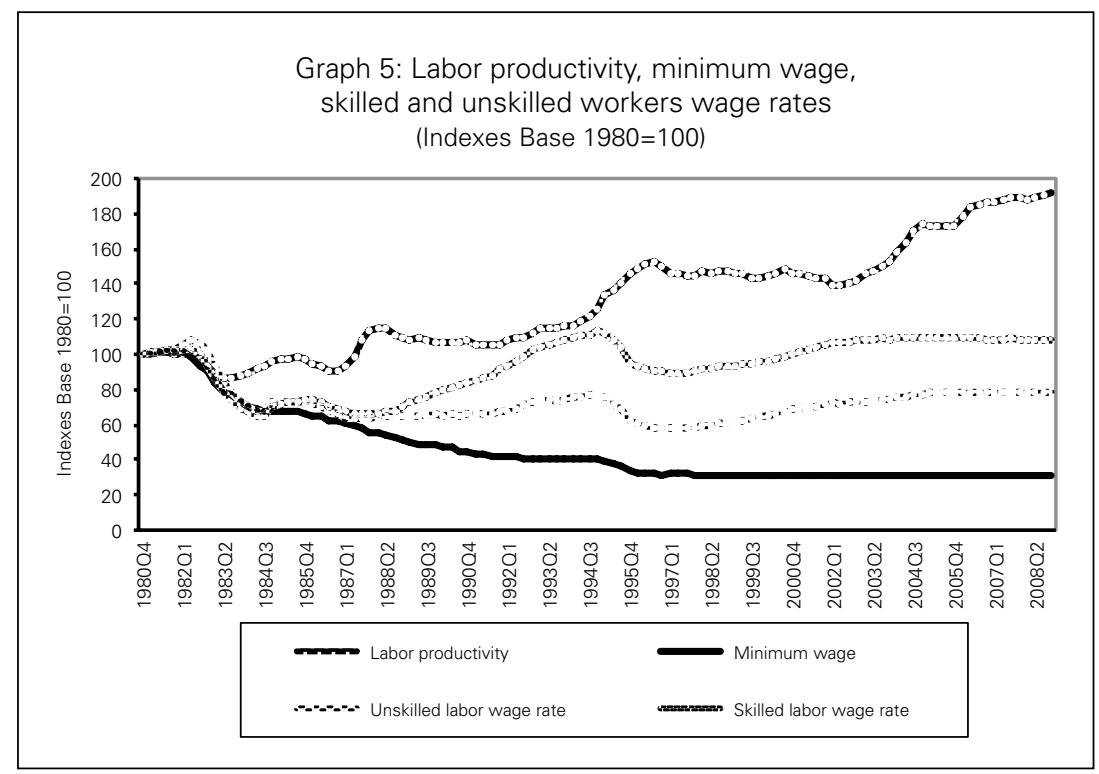

Source: Calculations based on data from banco de Mexico and INEGI.

\section{EXCHANGE RATE PASS-THROUGH AND FACTOR INCOME DISTRIBUTION IN MEXICO}

The three equation model proposed in Section 3 was empirically tested with quarterly data on the Mexican economy for the period 1980.1-2008.4.

The sample period was so defined in order to capture the large fluctuations in the exchange rate experienced after the 1982 and 1994 crises, as well as the persistent decline in employment and minimum wages from 1980 onwards.

Variables in the equations were proxied by the following indicators, and transformed into logarithms:

P Consumer Price Index

ER Inter-bank peso-US dollar exchange rate at the end of period

ULC Share of total labor income in output, in manufacturing industry

Wmin Minimum real wage index

DIF Ratio of white collar workers' average wage index to blue collar workers' average wage index, in manufacturing industry

EMP Index of employment in manufacturing industry

CRED Ratio of bank credit to monetary base

Since all the series in logarithms appeared to be integrated of order one (see Table 1), we explored cointegration by means of the Johansen procedure. 
Table 1: Augmented Dickey-Fuller and Phillips-Perron Unit Root Tests

\begin{tabular}{|c|c|c|c|c|c|c|c|c|}
\hline \multirow{2}{*}{$\begin{array}{l}\text { Variables } \\
\text { in logarithms }\end{array}$} & \multicolumn{3}{|c|}{ LEVELS } & \multirow[b]{2}{*}{ Test Conditions* } & \multicolumn{4}{|c|}{ 1st DIFFERENCES } \\
\hline & ADF Statistic & PP t-Statistic & PValue & & ADF Statistic & PP t-Statistic & P Value & Test conditions* \\
\hline \multirow[t]{3}{*}{$p$} & -1.203 & & 0.905 & C, T, AIC (5 lags) & -3.922 & & 0.014 & C, T, AIC(4 lags) \\
\hline & -1.678 & & 0.755 & C, T, SIC (3 lags) & -3.313 & & 0.069 & C,T, SIC (2 lags) \\
\hline & & -0.826 & 0.960 & $C_{,} T$ & & -3.884 & 0.016 & $C_{,} T$ \\
\hline \multirow[t]{3}{*}{ er } & -1.994 & & 0.598 & C, T, AIC(3 lags) & -3.734 & & 0.024 & C, T, AIC(2 lags) \\
\hline & -1.465 & & 0.836 & C, T, AIC(3 lags) & -7.488 & & 0.000 & C, T, SIC (O lag) \\
\hline & & -1.310 & 0.881 & $C_{,} T$ & & -7.800 & 0.000 & $C_{1} T$ \\
\hline \multirow[t]{3}{*}{ dif } & -1.567 & & 0.496 & C, AIC (6 lags) & -2.731 & & 0.007 & AIC (5 lags) \\
\hline & -1.276 & & 0.639 & C, SIC (4 lags) & -4.122 & & 0.000 & SIC (3 lags) \\
\hline & & -1.380 & 0.590 & C & & -14.774 & 0.000 & \\
\hline \multirow[t]{3}{*}{ emp } & -0.612 & & 0.862 & C, AIC (10 lags) & -3.202 & & 0.002 & AlC (8 lags) \\
\hline & -1.287 & & 0.634 & C, SIC (5 lags) & -4.342 & & 0.000 & SIC (4 Lags) \\
\hline & & -0.655 & 0.853 & C & & -6.673 & 0.000 & \\
\hline \multirow[t]{3}{*}{ cred } & -2.206 & & 0.206 & C, AIC (IL lags) & $-1 . / 63$ & & $0.0 / 4$ & AIC (1 1 lags) \\
\hline & -1.945 & & 0.310 & C, SIC (8 lags) & -2.446 & & 0.015 & SIC (7 lags) \\
\hline & & -1.715 & 0.421 & C & & -13.464 & 0.000 & \\
\hline \multirow[t]{3}{*}{$\mathrm{W}_{\min }$} & -0.403 & & 0.986 & C, T, AIC (7 lags) & -3.048 & & 0.003 & AIC (6 lags) \\
\hline & -0.940 & & 0.947 & C, T, SIC (4 lags) & -3.812 & & 0.000 & SIC (3 lags) \\
\hline & & -1.340 & 0.873 & $C_{1} T$ & & -15.076 & 0.000 & \\
\hline \multirow[t]{3}{*}{ ulc } & -2.162 & & 0.222 & C, AlC (12 lags) & -2.730 & & 0.007 & AIC (11 lags) \\
\hline & -2.021 & & 0.277 & C, SIC (7 lags) & -5.118 & & 0.000 & SIC (6 lags) \\
\hline & & -2.302 & 0.173 & C & & -12.519 & 0.000 & \\
\hline
\end{tabular}

${ }^{*} \mathrm{C}=$ Intercept $\quad \mathrm{T}=$ Trend $\quad \mathrm{SIC}=$ Schwartz information criterion $\quad$ AIC =Akaike information criterion

For the three equations we obtained cointegrating vectors. Table 2 shows the results, on the grounds of the trace statistic.

Table 2: Johansen cointegration test results

\begin{tabular}{|c|c|c|c|c|c|c|}
\hline & Equation & $\mathrm{Ho}$ & Trace Statistic & Critical Value (0.05) & Probability & Test Conditions \\
\hline (5.1) & $p=f(e r, u l c)$ & $\begin{array}{c}\text { None } \\
\text { At most one }\end{array}$ & $\begin{array}{l}48.478 \\
15.349\end{array}$ & $\begin{array}{l}29.797 \\
15.495\end{array}$ & $\begin{array}{l}0.000 \\
0.053\end{array}$ & $\begin{array}{l}\text { Deterministic trend in data } \\
\text { No intercept or trend } \\
\text { in CE or VAR } \\
1-2 \text { lags }\end{array}$ \\
\hline (5.2) & $u l c=f\left(\operatorname{dif}, w_{\text {min }}\right)$ & $\begin{array}{c}\text { None } \\
\text { At most one }\end{array}$ & $\begin{array}{l}41.633 \\
15.753\end{array}$ & $\begin{array}{l}35.193 \\
20.262\end{array}$ & $\begin{array}{l}0.009 \\
0.186\end{array}$ & $\begin{array}{l}\text { Intercept in CE } \\
\text { No intercept in VAR } \\
\text { 1-4 lags }\end{array}$ \\
\hline (5.3) & dif $=f($ cred, emp $)$ & $\begin{array}{c}\text { None } \\
\text { At most one }\end{array}$ & $\begin{array}{l}47.447 \\
14.930\end{array}$ & $\begin{array}{l}35.193 \\
20.262\end{array}$ & $\begin{array}{l}0.002 \\
0.230\end{array}$ & $\begin{array}{l}\text { Intercept in CE } \\
\text { No intercept in VAR } \\
\text { 1-4 lags }\end{array}$ \\
\hline
\end{tabular}


All the variables in the cointegrating vectors showed the expected signs. Table 3 summarizes these results.

Table 3: Estimated equations by the method of cointegration

\begin{tabular}{|c|c|c|c|c|}
\hline Equation & Dependent variable & \multicolumn{3}{|c|}{ Independent Variables $\left({ }^{*}\right)$} \\
\hline [5.1] & $\mathrm{p}$ & $\begin{array}{c}\text { er } \\
0.915 \\
{[0.036]}\end{array}$ & $\begin{array}{c}\text { ulc } \\
-1.125 \\
{[0.292]}\end{array}$ & \\
\hline [5.2] & ulc & $\begin{array}{c}\text { dif } \\
2.912 \\
{[0.890]}\end{array}$ & $\begin{array}{c}W_{\min } \\
2.297 \\
{[0.421]}\end{array}$ & $\begin{array}{c}\text { Constant term } \\
-8.743 \\
{[2.732]}\end{array}$ \\
\hline [5.3] & dif & $\begin{array}{c}\text { cred } \\
0.185 \\
{[0.021]}\end{array}$ & $\begin{array}{c}\text { emp } \\
-0.615 \\
{[0.094]}\end{array}$ & $\begin{array}{c}\text { Constant term } \\
3.430 \\
{[0.451]}\end{array}$ \\
\hline
\end{tabular}

$\left({ }^{*}\right)$ Figures in parenthesis below coefficients are standard errors

Equation (5.1) shows that in Mexico, unlike what is observed in developed countries (Calvo and Reinhart, 2000; Arestis and Milberg, 1994), exchange rate pass-through inflation is high, and unit labor costs are negatively associated with inflation rates. The estimated elasticity of inflation with respect to the exchange rate is 0.915 , and is not very different from the unit value obtained by Garcés (1999).

The high, negative elasticity of inflation to a change in labor costs, -1.125 , suggests that in Mexico, a fall in employment and wage rates has a strong negative effect on aggregate demand, and induces oligopolistic firms to adjust their supply rather than pass over to prices the fall in labor costs. This result is consistent with Verdoorn's principle.

Equation (5.2) measures the influence of skilled workers' wage differentials and the institutional minimum wage (which is a basic reference in secondary labor markets) on unit labor cost. The estimated elasticities are notably high, 2.3 and 2.9, respectively, which reflects the strong effects that changes in employment exert on labor incomes. The negative constant term is consistent with the long-run effects of technical progress.

Equation (5.3) provides support to our beliefs about the role of skilled labor wage differentials as shock-absorbers that stabilize the profit rate.

The high, negative elasticity (-0.62) of skilled workers' wage differentials with respect to employment can be explained by the isolation of primary labor markets from outsiders' competition, and the discretional administration of internal wage structures. Meanwhile, the positive influence of credit on wage spreads reflects firms' lower reliance on internal funds for investment when they have easy access to external finance.

In addition, the significance of the constant term corroborates labor market 
theory predictions about the constancy of wage differentials between skilled and unskilled workers, because of their dependence on social structure and conventions.

As a final point, this equation suggests that, in a developing economy, the cost of external funds does not exert a significant influence on oligopolistic firms' markup, as Eichner envisaged. Rather, innovating entrepreneurs are able to transfer backwards, to the skilled labor market, the financial constraints on their desired investment.

\section{CONCLUDING REMARKS}

We have attempted to demonstrate that two traits of a developing economy, namely its dependence on imported technology, intermediates and capital goods, and its excess supply of unskilled labor, bring about significant differences in the way the price level responds to exchange rate variations, bank credit expansion and wage rate increases, as compared with a developed economy.

It has been argued that in a semi-industrialized economy, local currency depreciation has a large inflationary effect because domestic firms' market power is entrenched in imported capital goods; and because this inflationary response induces tight credit policies that raise interest rates.

We contended that, as a result of the increased international mobility of financial capital and the fixity of labor, in an open economy profits are the prior deduction in income distribution, and wages are the residual. In conformity with segmented labor market theory, we concluded that price leading firms discretionally share amongst their skilled workers the productivity gains from embodied technical progress. Therefore, skilled labor wage increases should not be considered a source of inflationary pressures.

We maintained that when a desired rate of accumulation determines firms' mark-up over costs, expansionary credit policies may actually become deflationary. Only when flexible credit policies bring about an excess of imports over exports that leads to currency devaluation, they become inflationary. Hence, for a developing economy the limit to credit expansion is given by Thirlwall's law.

From these premises it follows that a developing economy may achieve higher rates of growth, and a more equitable distribution of income, by means of an expansionary credit policy, provided it satisfies the following conditions:

1. Credit finances projects that increase total factor productivity.

2. Credit is allocated in activities that lower the income elasticity of imports and/or raise the income elasticity of exports.

3. The financial structure efficiently transforms short term bank credit into long term investment funding (Davidson, 1986).

In a retrospective look at the industrialization policies implemented in Southeast Asia and Latin America, it is clear that in the former region these three conditions were adequately met, from the mid-1960s onwards (Lall, 1997; Bustelo, 
1992). Latin American countries, by contrast, failed to link their credit policies to a long-run industrialization strategy; they regulated bank loans mainly as a means to stabilize the trade account of the balance of payments (Studart, 1998). It is not surprising, thus, that the former region had registered much higher rates of growth and lower degrees of income inequality than the latter, during the last four decades.

\section{REFERENCES}

ALVAREZ, A. (2002) "La inestabilidad financiera internacional y sus implicaciones en México", in Mántey G., N. Levy (eds.), Globalización Financiera e Integración Monetaria: Una Perspectiva desde los Países en Desarrollo, UNAM-M. A. Porrúa, Mexico.

AMPUDIA, N. C. (2007) "Política monetaria, restricción crediticia y empleo”, in G. Mántey, N. Levy (eds.), Políticas Macroeconómicas para Países en Desarrollo, UNAM-M. A. Porrúa, Mexico.

ARESTIS, P. and W. MILBERG (1994) "Degree of Monopoly, pricing and flexible exchange rates", Journal of Post-Keynesian Economics, 16 (2): 167-88.

ARESTIS, P. and F. SKUSE (1991) "Wage and price setting in a Post-Keynesian theory of inflation", Economies et Societés, 25 (11-12): 91-106.

BALL, L. (2000) "Policy rules and external shocks", NBER Working Paper, No. 7910, September.

BAQUEIRO, A., A. DÍAZ DE LEÓN and A. TORRES GARCÍA (2003) “¿Temor a la flotación o a la inflación? La importancia del 'traspaso' del tipo de cambio a los precios”, Banco de México Documentos de Investigación, No. 2003-02.

BARDSEN, G., E. S. JANSEN and R. NYMOEN (2004) "Econometric evaluation of the New Keynesian Phillips Curve", Oxford Bulletin of Economics and Statistics, 66, Supplement: 671-686.

BIELCHOWSKY, R. (1998) "Cincuenta años del pensamiento de la CEPAL: una reseña”, in Cincuenta Años de Pensamiento en la CEPAL: Textos Escogidos, Fondo de Cultura Económica-CEPAL, Santiago.

BLANCHFLOWER, D. G., A. J. OSWALD and P. SANFEY (1996) "Wages, profits, and rent-sharing", Quarterly Journal of Economics, 111 (1): 227-51.

BUSTELO, P. (1992) "La industrialización en América Latina y Asia Oriental: un análisis comparado”, Comercio Exterior, 42 (12): 1111-19.

CALVO, G. A. and C. M. REINHART (2000) "Fixing for your life”, NBER Working Paper, No. 8006, November.

CAMARA, A. and M. VERNENGO (2001) “The German balance of payments school and the Latin American Neo-structuralists", in L. P. Rochon and M. Vernengo (eds.), Credit, Interest Rates and the Open Economy, Edward Elgar, Cheltenham.

CHENERY, H. P. and M. BRUNO (1962) "Development alternatives in an open economy: the case of Israel”, The Economic Journal, 72 (285): 79-103.

DAVIDSON, P. (1986) "Finance, funding, saving and investment", Journal of Post-Keynesian Economics, 9 (1): 101-10.

EICHENGREEN, B. (2002) “Can emerging markets float? should they inflation target?”, Banco Central do Brasil Working Paper Series, No. 36, February.

EICHENGREEN, B., R. HAUSMANN and U. PANIZZA (2003) "Currency mismatches, debt intolerance nd original sin: why they are not the same and why it matters", NBER Working Paper Series, No. 10036, October.

EICHNER, A. S. (1988) "Una teoría de la determinación del margen de ganancia en el oligopolio", in Ocampo J. A. (ed.), Economía Poskeynesiana, Fondo de Cultura Económica, Serie Lecturas, No. 60, Mexico.

FITZGERALD, V. (2005) “Monetary models and inflation targeting in emerging market economies", in Arestis P., Baddeley M. and McCombie J. (eds.), The New Monetary Policy, Edward Elgar, Cheltenham. 
GALÍ, J., M. GERTLER and J. D. LÓPEZ-SALIDO (2001) “European inflation dynamics”, European Economic Review, 45: 1237-1270.

GALINDO, L. M., R. ESCALANTE and H. CATALÁN (2007) "Modelo econométrico dinámico y estable de la tasa de inflación en México con bandas de probabilidad”, Comercio Exterior, 57(8): 618-631.

GARCÉS, D. (1999) “Determinación del nivel de precios y dinámica inflacionaria en México”, Banco de México, Documento de Investigación No. 9907.

GORDON, D. M. (1972) Theories of Poverty and Underemployment, D. C. Heath, Lexington Mass.

HALL, R. L. and HITCH C. J. (1939) "Price theory and business behavior", Oxford Economic Papers, 2, reprinted in Sawyer M. C. (ed.) (1988): Schools of Thought in Economics, Vol. 2, Post-Keynesian Economics. Edward Elgar, Aldershot.

HAUSMANN, R., H. PANIZZA and E. STEIN (2001) "Why do countries float the way they float?", Journal of Development Economics, 66: 387-414.

HERNÁNDEZ-BARRIGA, P. (2009) “Tipos de cambio e inflación en América Latina”, in Mántey G., López T. S. (eds.), Política Monetaria con Elevado Traspaso del Tipo de Cambio. La Experiencia Mexicana con Metas de Inflación, UNAM-Plaza y Valdés, Mexico.

KALECKI, M. (1956) Teoría de la Dinámica Económica, Fondo de Cultura Económica, México.

KRUGMAN, P. and BALDWIN R. (1987) “The persistence of the U. S. trade deficit”, Brookings Papers on Economic Activity, (1): 1-43.

KRUGMAN, P. and L. TAYLOR (1978) “Contractionary effects of devaluation”, Journal of International Economics, 8(3): 445-56.

LALL, S. (1997) "Selective policies for export promotion: Lessons from the Asian Tigers", Research for Action, No. 43, United Nations University WIDER.

LEONTARIDI, M. R. (1998) "Segmented labor markets: theory and evidence”, Journal of Economic Surveys, 12 (1): 63-101.

LÓPEZ, A. and LÓPEZ J. (2006): "Manufacturing real wages in Mexico", Brazilian Journal of Political Economy, 26 (3): 459-74.

LUSTIG, N. (1988) "Del estructuralismo al neo-estructuralismo: la búsqueda de un paradigma heterodoxo”, Colección Estudios CIEPLAN, 23: 35-50.

MÁNTEY, G. (2005) "Salarios, dinero e inflación”, in Mántey G., Levy N. (eds.), Inflación, Crédito y Salarios: Nuevos Enfoques de Política Monetaria para Mercados Imperfectos, UNAM-M. A. Porrúa, Mexico.

MÁNTEY, G. (2006) "Inflation targeting and exchange rate risk in emerging economies subject to structural inflation", in S. Motamen-Samadian (ed.), Economic and Financial Developments in Latin America, Palgrave Macmillan, New York.

NOYOLA, J. F. (1957) “Inflación y desarrollo económico en Chile y México”, Panorama Económico, 11(170), reprinted in CEPAL (1998): Cincuenta Años de Pensamiento en la CEPAL, FCE-CEPAL, Santiago.

PALLEY, T. I. (2001) "Escaping the policy credibility trap: reshaping the debate over the international financial architecture", Problemas del Desarrollo, 32 (126): 111-24.

PANICO, C. and N. SALVADORI (2006) "Introduction", in N. Salvadori and C. Panico (eds.), Classical, Neoclassical and Keynesian Views on Growth and Distribution, E. Elgar, Cheltenham.

PINTO, A. (1975) Inflación: Raíces Estructurales, Fondo de Cultura Económica, Lecturas del FCE No. 3, Mexico.

PIORE, M. J. (1971) “The dual labor market: theory and implications”, in Gordon D. M. (ed.), Problems in Political Economy: An Urban Perspective, D. C. Heath, Lexington Mass.

PREBISCH, R. (1949) "El desarrollo económico de la América Latina y algunos de sus principales problemas", Trimestre Económico, 16 (63): 347-431.

PREBISCH, R. (1983) “Cinco etapas de mi pensamiento sobre el desarrollo”, Trimestre Económico, 50 (198): 1077-96.

ROBINSON, J. (1966) The Accumulation of Capital, Macmillan, London.

RODRÍGUEZ, O. (1980) La Teoría del Subdesarrollo de la CEPAL, Siglo XXI, Mexico. 
ROME, D. (2000) “Keynesian macroeconomics without the LM curve”, Journal of Economic Perspectives, 14(2): 149-169.

SAWYER, M. (1982) "Collective bargaining, oligopoly and macroeconomics", Oxford Economic Papers, 34 (3): 428-48.

STUDART, R. (1998) "Políticas financieras y crecimiento en el contexto del desarrollo: lecciones derivadas de América Latina y del Sudeste Asiático en los años ochenta", Investigación Económica, 57 (224): $15-42$

SVENSSON, L. E. O. (1997) "Inflation forecast targeting: implementing and monitoring inflation targets", European Economic Review, 41: 1111-1146.

SVENSSON, L. E. O. (2000) “Open economy inflation targeting”, Journal of International Economics, 50: $155-183$.

TAYLOR, L. (1983) Structuralist Macroeconomics. Applicable Models for the Third World, Basic Books Inc., New York.

THIRLWALL, A. P. (1979) "The balance of payments constraint as an explanation of international growth differences", Banca Nazionale del Lavoro Quarterly Review, 128: 45-53.

THIRLWALL, A. P. (2003) Trade, the Balance of Payments and Exchange Rate Policy in Developing Countries, Edward Elgar, Cheltenham. 